\title{
U. Public-Water Supplies in Massachusetts and Phode Island: Investigations of Processes Affecting Source-Water Quality
}

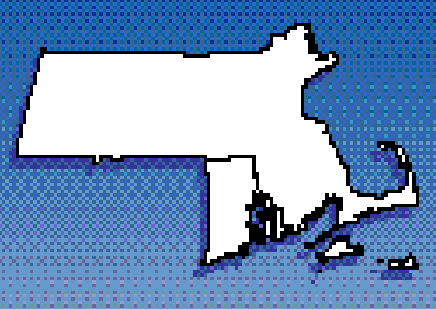

\author{
US. Department of the Interior - U.S. Geological Survey
}

\section{Introduction}

Drinking-water needs in

Massachusetts and Rhode Island are supplied by a combination of surfacewater and ground-water resources. Urban areas in the two States obtain most of their drinking water from reservoirs; 65 percent of the 6 million people in Massachusetts and 75 percent of the 1 million people in Rhode Island depend on surface-water supplies. Most people who live outside of major urban areas in the two States obtain their drinking water from wells completed in unconfined stratified-drift aquifers, several of which have been designated sole-source aquifers.

Surface-water and ground-water supplies in Massachusetts and Rhode Island have been affected by natural and manmade contaminants that have the potential for adversely affecting human health. Drainage areas surrounding major water-supply reservoirs are attractive areas for development and in recent years have received increasing amounts of toxic chemicals, nutrients, and human pathogens. Many of the ground-water sources are stratified-drift aquifers that are less than 100 feet thick. Because these deposits are permeable, water in the aquifers is highly susceptible to contamination from anthropogenic activities on the land surface.

The U.S.Geological Survey (USGS), in cooperation with State and local agencies, is investigating problems related to contamination and long-term protection of drinking-water supplies in Massachusetts and Rhode Island.

Current investigations range from a classification of small watersheds in the drainage basin of a major drinking-water supply reservoir to an assessment of the vulnerability of public ground-water supplies to contamination. State and local officials charged with protecting drinking-water supplies benefit from these investigations through an increased understanding of the natural and humaninfluenced processes that affect sourcewater quality in Massachusetts and Rhode Island. This fact sheet summarizes these investigations.

\section{Water-Supply Reservoirs in Massachusetts and Rhode Island}

Large reservoir systems provide drinking water to much of central and eastern Massachusetts and Rhode Island (fig. 1). The systems include the QuabbinWachusett Reservoir system and the Worcester Reservoir system in central Massachusetts, the Cambridge Reservoir system in eastern Massachusetts, and the Scituate Reservoir system in Rhode Island. These reservoir systems were developed during the late 19th and early 20th centuries when only minimal treatment was needed to meet safe drinking-water standards. However,

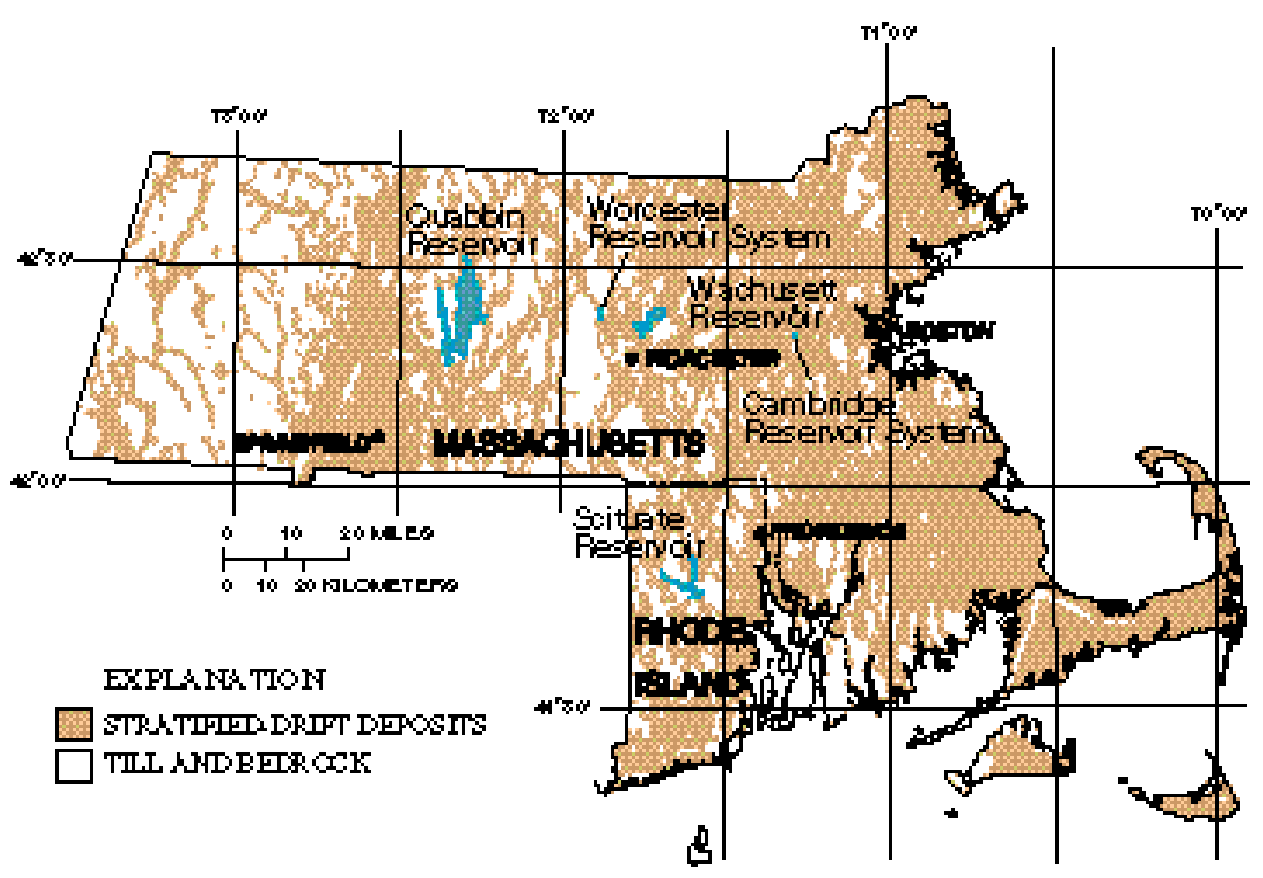

Figure 1. Location of large water-supply reservoirs and stratified-drift deposits in Massachusetts and Rhode Island. 
population growth and development of land in the drainage basins that supply the reservoirs has resulted in increased transport of nutrients, contaminants, and pathogens to the systems; at the same time, drinking-water standards have become more stringent, requiring improved protection of source-water quality and more extensive water treatment. State officials charged with protecting drinking-water resources require information on sources of pollutants in the watersheds and on hydrologic processes and interactions that move these pollutants through the watersheds. This information assists the officials in decisions on how to allocate limited financial resources among various watershed-protection and watertreatment alternatives.

\section{Ground-Water Supply Sources in Massachusetts and Rhode Island}

Stratified-drift aquifers provide water for virtually all large public-supply wells in Massachusetts and Rhode Island (fig.1). These aquifers can be divided into two hydrogeological terranes: alluvial valleys and outwash plains. Alluvial-valley aquifers along many of the major streams tend to have small volume and storage, yet can be productive because of induced infiltration from the traversing streams. Outwash-plain aquifers are areas of low relief underlain by large volumes of drift deposited as outwash beyond glacial end moraines. Several of the major outwashplain aquifers in Massachusetts and Rhode Island have been designated solesource aquifers, including Cape Cod, Martha's Vineyard, Nantucket Island, and Plymouth-Carver aquifers in Massachusetts, and Block Island, Pawcatuck River Basin, and Hunt River Basin aquifers in Rhode Island.

Stratified-drift aquifers are susceptible to contamination because they are near the land surface in urbanized areas, the generally high hydraulic conductivity of overlying unsaturated-zone deposits, and the high annual rates of precipitation recharge.

\section{Source-Water Quality Issues and Concerns}

\section{Reservoir Water Quality}

Reservoir-water quality in

Massachusetts and Rhode Island is at risk because of continued urbanization in the watersheds. Specific concerns include (1) nutrient enrichment leading to eutrophication and growth of undesirable algal and macrophyte species; (2) transport of viruses, fecal bacteria, and protozoan pathogens such as Giardia and Cryptosporidium; (3) formation of toxic organohalogen compounds from naturally occurring organic matter as a by-product of disinfection; (4) episodic releases of toxic chemicals resulting from accidental spills or road-salt applications; and (5) loss of reservoir storage due to sedimentation.

\section{Ground-Water Quality}

Ground-water supplies in Massachusetts and Rhode Island also are at risk because of continued anthropogenic activity. Specific concerns include (1) nitrate contamination from nonpoint sources and point sources including nutrient enrichment of ground water (by nitrate) by residential septic tanks and municipal sewage disposal at rapid infiltration facilities; (2) trace-element contamination of ground water from natural and anthropogenic sources, including radon, arsenic, iron, and manganese from natural sources, and mercury, chromium, and other metals from industrial operations; (3) pesticide contamination from agricultural activities and other sources, including residential lawns and golf courses; and (4) contamination by volatile organic compounds from industrial, wastedisposal, and military sites.

\section{Ongoing Source-Water- Quality Investigations}

The Massachusetts/Rhode Island District of USGS has established monitoring and investigative programs to characterize and anticipate changing quality and quantity of the most important drinking-water sources in the two States. These studies will provide the Earth-science information to develop more efficient, appropriate, and costeffective water-treatment methods and source-water protection strategies.

\section{Characterizing Small Watersheds in the Quabbin Reservoir Basin}

Quabbin Reservoir (fig. 2) provides high-quality drinking water to 2.5 million people in 43 communities in central and eastern Massachusetts. Quabbin Reservoir is one of five large drinking-water supply reservoirs in the country that are not required to use filtration. About 65 percent of the 96,000-acre Quabbin Reservoir Basin is managed by the Metropolitan District Commission (MDC) and preserved as State-owned forest land. MDC is responsible for protecting the quantity and quality of water discharging from the drainage basin to the reservoir. The USGS and MDC are cooperating in a study to characterize existing water-quality and geographic information about small watersheds in the Quabbin Reservoir Basin. Wetlands, composition of soil and aquifer material, and road density are dominant controls on source-water quality in the basin. Waterquality and geographic data collected by the USGS, the MDC, the University of Massachusetts, and the Massachusetts Department of Environmental Protection were used to refine watershed classification.

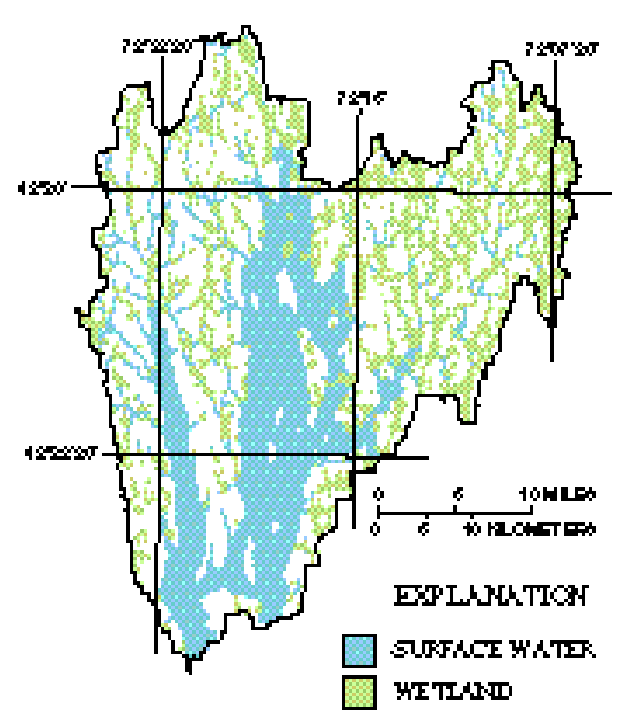

Figure 2. Hydrology of the Quabbin Reservoir Basin. 


\section{Quantity and Quality of Source Water to the Scituate Reservoir}

The Scituate Reservoir system is the principal source of drinking water for the State of Rhode Island (fig. 3). The USGS, in cooperation with the Providence Water Supply Board (PWSB), and the Rhode Island Department of Environmental Management, is assessing the flow and quality of water in the streams that contribute to the reservoir. Low-flow estimates provide the basis for formulating surface-water and groundwater basin-yield estimates. The USGS, in cooperation with the PWSB, also is evaluating the status and trends of waterquality conditions in streams that contribute to the reservoir. The PWSB will use this information to improve watershed management practices and protect the quality of source water in the reservoir basin.

\section{Sources of Salt to the Cambridge Reservoir}

The Cambridge Reservoir system is the principal source of drinking water for Cambridge, Mass. The reservoir system is west of Boston in a highly urbanized area. Recently, elevated concentrations of sodium were detected in the reservoir.

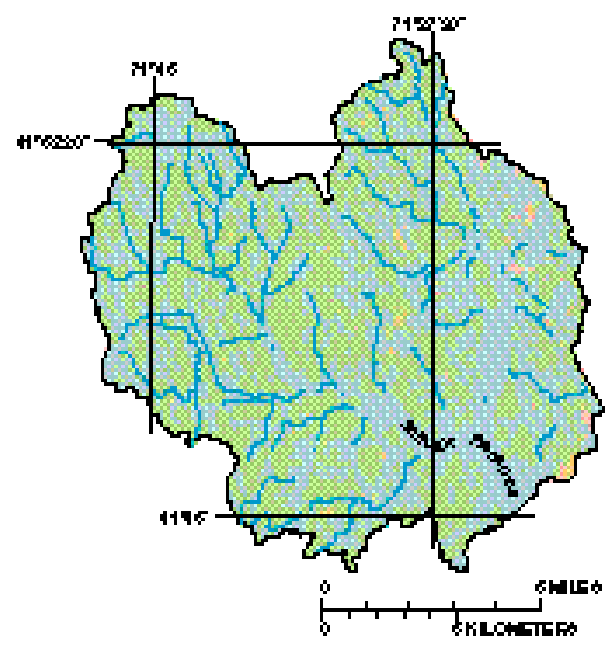

EXPLWNTTON

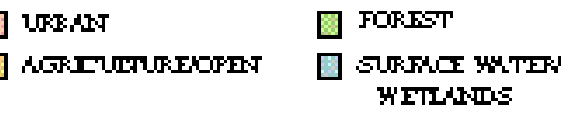

Figure 3. Land use in the Scituate Reservoir Basin, Rhode Island.
The USGS, in cooperation with the Massachusetts Highway Department, is assessing the hydrology of the system and the sources of water and salts to the reservoir.

\section{Vulnerability of Public Ground- Water Supplies in Rhode Island}

Ground water supplies two-thirds of Rhode Island communities with some or all of their drinking water (fig. 4). Waterquality monitoring requirements for ground-water supplies are determined by the U.S. Environmental Protection Agency (USEPA) and State regulatory agencies. Recently, USEPA developed a draft proposal for reforming monitoring requirements for community water systems (CWS) and non-transient, noncommunity water systems (NTNCWS). As part of the reform, States would be required to develop individual monitoring programs that focus on the most vulnerable public supply points within a common contributing area. The USGS, in cooperation with the Rhode Island Department of Health (RIDOH), is assessing the relative vulnerability of CWS and NTNCWS to specific classes of natural and manmade contaminants (for example, organic compounds, pesticides, and trace elements) using land-use data, wellhead-protection areas, aquifer and well characteristics, and historical water-quality data. Results of the investigation will help RIDOH define the factors that affect the vulnerability of the State's CWS and NTNCWS to contaminants and to develop appropriate monitoring programs.

\section{Identification of Potential Public Water-Supply Areas on Cape Cod}

Ground water is the sole source of drinking water to most of Cape Cod. In general, ground water underlying Cape Cod is abundant and of good quality. Past contamination and changing land use, however, in particular the rapid development of open land, may seriously limit the water-supply potential of the ground-water resource through degradation of water quality. The USGS, in cooperation with the Cape Cod Commission, identified and ranked potential public water-supply areas on Cape Cod using a geographic information system (fig. 5).

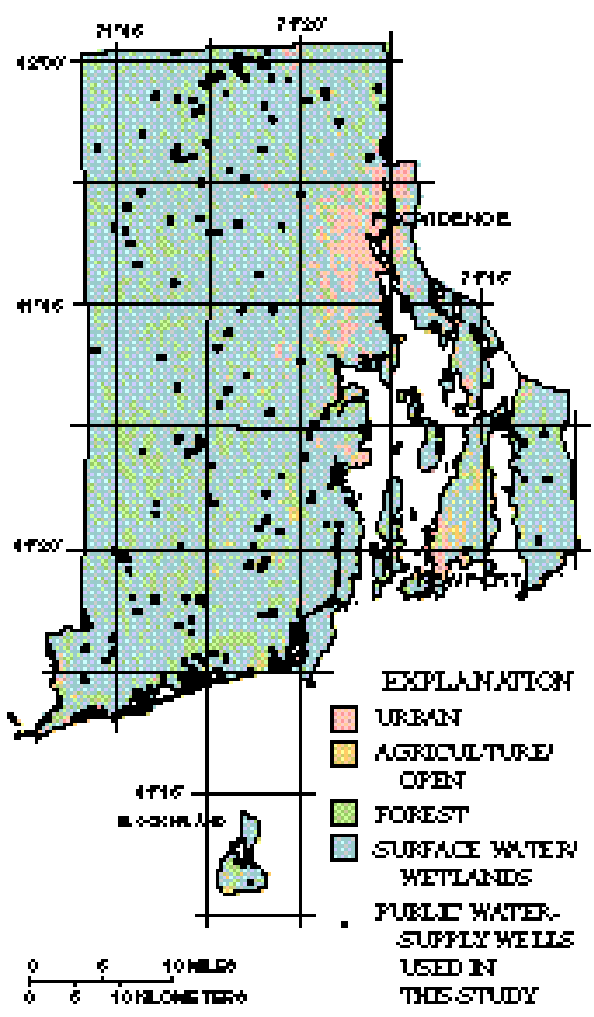

Figure 4. Land use and location of public supply wells in Rhode Island.

Results of the study will help the Cape Cod Commission manage and protect the ground-water resources on Cape Cod.

\section{Ongoing Regional-Water Quality Investigations}

\section{National Water-Quality Assessment}

The National Water-Quality Assessment (NAWQA) Program was undertaken to describe the status and trends of a large representative part of the Nation's surface- and ground-water resources and to identify the natural and human factors that affect the quality of these resources. The NAWQA Program will provide a wealth of information useful to policymakers and water managers at local, State, and national levels.

Investigations of three NAWQA Program study units are underway in Massachusetts: the Connecticut, Housatonic, and Thames Rivers Basins; New England Coastal Basins; and the Hudson River Basin. Results from the Connecticut, Housatonic, and Thames Rivers study include (1) detection of pesticides in many streams draining urban 


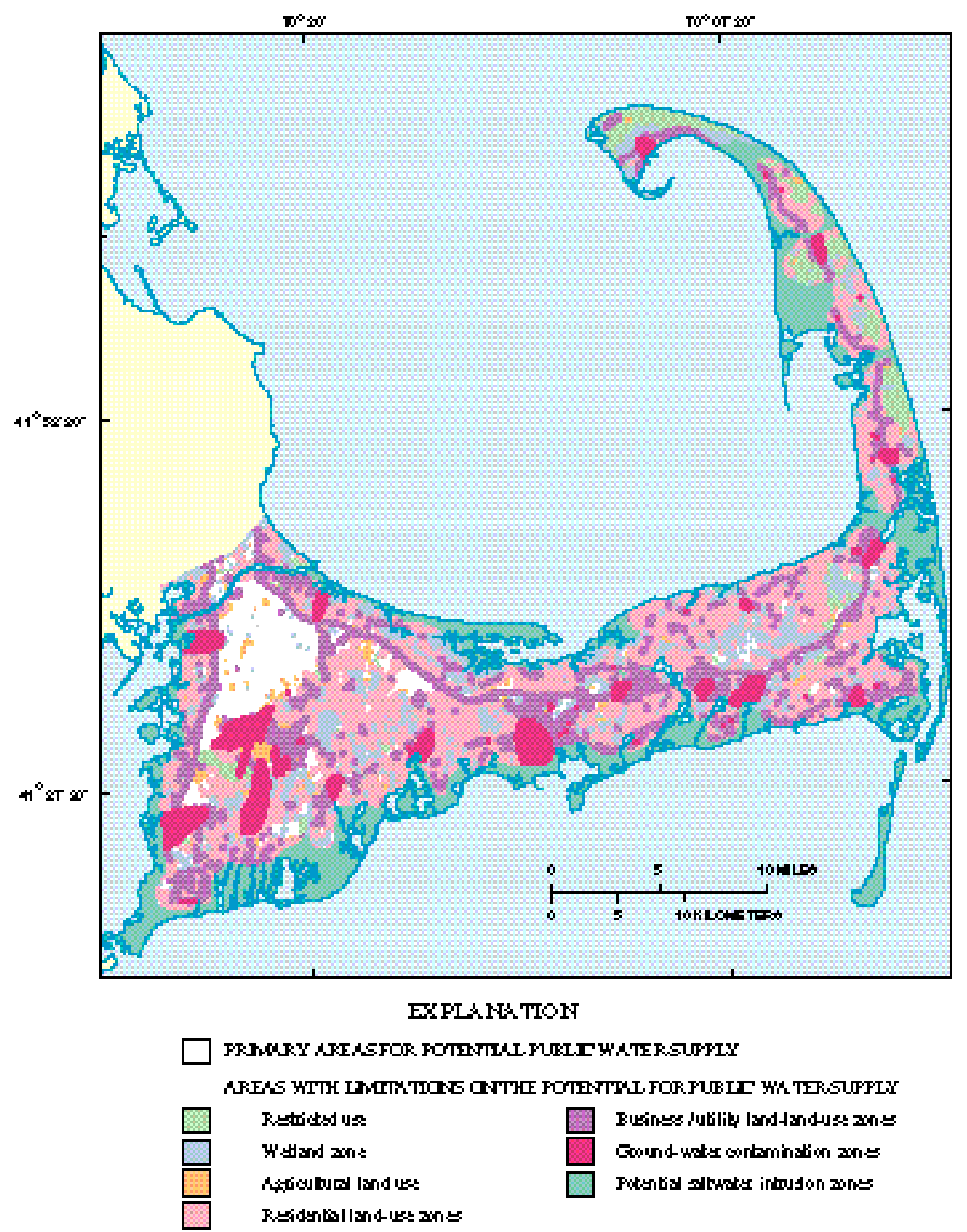

Figure 5. Land use in relation to potential sources of public-water supply on Cape Cod, Massachusetts.

areas and large tracts of agricultural land; (2) detection of volatile organic compounds (VOCs), generally petroleum compounds, including the gasoline additive methyl tert-butyl ether (MTBE) and solvents, in shallow wells completed in glacial sand and gravel aquifers beneath urban areas; (3) higher concentrations of USEPA Priority Pollutants, including antimony, cadmium, copper, lead, mercury, silver, and zinc, along with sulfur, in river-bed-sediment samples in areas of high urban land use than in rural areas; (4) detection of PCB's and DDE (a DDT metabolite) in fish tissue sampled throughout the study area. PCB concentrations were highest on the Housatonic River.

\section{River-Basin Studies in Massachusetts}

The Massachusetts Department of Environmental Management (MDEM) is responsible for developing management plans for the efficient and environmentally sound use of water in the State's 27 riverbasin planning units. The USGS has been conducting studies in the planning units to obtain information needed by MDEM to develop their management plans. This information may include boundaries, recharge, and water-bearing properties of aquifers, streamflow characteristics, water use, water quality, surface-water and ground-water interactions, and streamsediment transport. Other USGS and MDEM cooperative studies include determining low-flow statistics for streams throughout Massachusetts, and tracking the withdrawal, distribution, use, and return of water by municipal, agricultural, commercial, and industrial water users.

Information from these studies provides a basis for water-resource decision making in Massachusetts. Other State, regional, and local agencies use the information to help locate potential new water-supply sources, to design wastewater-treatment and other facilities, and to assess water withdrawals and interbasin water transfers.

Environmental groups also use the information to advocate for and design resource-protection areas.

\section{Benefits and Transferability}

The ongoing USGS investigations will develop, implement, and test new technologies to assess source-water quality to large reservoirs and groundwater resources in Massachusetts and Rhode Island. Furthermore, the reservoir source-water quality issues and the ground-water quality issues addressed in these studies are not limited to New England; the technical expertise and information developed by these investigations will benefit water-resource managers across the Nation. Also, because of the large population in the study area, results of the ongoing investigations will be useful in formulating a National synthesis of drinking-water data.

-Robert M. Lent, Marcus C. Waldron, and John C. Rader

For further information contact: District Chief U.S. Geological Survey 28 Lord Road, Suite 280 Marlborough, Massachusetts 01752

Internet: http://www.usgs.gov 